\title{
Brug af internettet til støtte for samarbejde og videndeling
}

\author{
Jens Dørup \\ Lektor, Dr. Med. \\ Sektionen for Sundhedsinformatik \& \\ E-læringsenheden \\ Aarhus Universitet \\ jd@hi.au.dk \\ http://www.hi.au.dk/jd
}

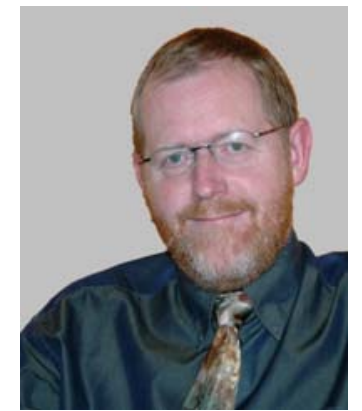

Jens Dørup er leder af Aarhus Universitets e-lcringsenhed (se http://www.iktlab.au.dk og http://www.e-learning.au.dk) og af Sektionen for Sundhedsinformatik, Institut for folkesundhed, Aarhus Universitet; næestformand for Dansk Selskab for Medicinsk Uddannelse (http://www.dsmu.dk); bestyrelsesmedlem i Society for the Internet in Medicine (http://www.internet-in-medicine.org ) og bestyrelsesmedlem i EUNIS (European University Information Systems, http://www.eunis.org).

\section{Indledning}

Mange, som i dag vil dele information via internettet, vælger at sende en e-mail. Med e-mail kan man nå en veldefineret gruppe mennesker, man kan være nogenlunde sikker på, at de får beskeden og at de læser den. Helt sikker kan man dog ikke være. Man kan bede om en kvittering for modtagelsen, men det hjælper kun lidt. Mails, som filtreres fra, får man nemlig ikke kvittering for, og man kan ikke vide, om modtageren ønsker at kvittere for modtagelsen. En fordel ved E-mail er at den både er interaktiv og asynkron. Man kan svare, men behøver ikke gøre det lige nu. Sammenlignet med de synkrone alternativer, tillader den asynkrone kommunikation, at man i en periode uforstyrret kan arbejde videre med det, man aktuelt er i gang med og vente til en mere passende lejlighed, med at forholde sig til den aktuelle mail. Af og til må man dog gribe "røret” og vende en sag i telefonen og sikre sig, at beskeden er nået frem og forstået på den tiltænkte måde. På trods af fordelene er der problemer med at bruge e-mail, som det eneste grundlag for et effektivt samarbejde via nettet. De fleste kan sikkert nikke genkendende til følgende problemer:

- Jeg er hjemme lige nu. Den mail, du sendte, ligger på arbejdet.

- Jeg kan ikke se, at du har vedhreftet noget til din mail.

- Den gamle mail har jeg slettet for at få mere plads. Kan du ikke lige sende den igen?

- Jeg mener, at jeg gemte det dokument, men hvor var det nu, at jeg gemte det?

- Jeg får så meget spam - måske er din mail gået i spamfilteret, eller jeg er kommet til at slette den.

- Din mail blev afvist. Måske var det fordi, den vedhreftede fil var for stor, eller systemet troede, at der var virus i den.

Hvis information har en lidt mere permanent karakter, kan man sørge for, at der bliver lagt en kopi på en webserver, så andre kan tilgå data i den kommende tid. At dette er nyttigt, er der jo ikke så megen tvivl om, men for mange såkaldt almindelige mennesker er det stadig ikke en dagligdags begivenhed at lægge information på nettet - og langt mindre at fjerne eller modificere den. Dette er på sin vis paradoksalt, for allerede da grundstenene til World Wide Web blev lagt, var der planer om, at webbrowsere ikke blot skulle være værktøjer til at se informa- 
tion, men også skulle have redigeringsfunktioner, så brugerne kunne bidrage til at gøre internettet til hver mands eje og altså også til et værktøj til støtte for samarbejde om fx at fremstille et fælles dokument \{Berners-Lee, 20013538 /id\}. I webbrowseren Mozilla findes faktisk en redigeringsknap, så man kan tage en kopi af en hjemmeside, redigere den og eventuelt gemme den på en server og herved i princippet benytte information fra WWW i et fælles dokument og i en samarbejdsproces. I praksis er webbrowseren dog ikke i sig selv et tilstrækkeligt værktøj til at understøtte samarbejde og videndeling og som vi skal se er der da også udviklet andre alternativer.

For de fleste universitetsundervisere og forskere er WWW og e-mail blevet en selvfølgelig del af den daglige kommunikation - WWW til envejskommunikation, e-mail til to- eller flervejs. I nærværende artikel vil jeg med udgangspunkt i praktiske erfaringer fra nationale og internationale samarbejdsprojekter illustrere og diskutere, hvordan internettet kan bidrage med andet og mere end blot e-mail og web-sider, og hvordan en bevidst brug af enkle værktøjer kan være med til at løse nogle af de problemer, man kan ofte støder på.

Der findes et væld af systemer, som lover hjælp med samarbejde og videndeling via nettet. Nogle systemer er simple, andre meget komplekse, og priserne varierer fra nul til millioner af kroner. I denne sammenhæng vil jeg kun omtale systemer, som jeg har en vis praktisk erfaring med og som kan være nyttige for en gennemsnitlig universitetsunderviser. De tre vigtigste kriterier er her:

1. Det skal vœre effektivt: Opgaven skal løses på tilfredsstillende måde. For megen støj på IP-telefonen - og den bliver udskiftet med den gamle telefon.

2. Det skal være simpelt: Hvis et samarbejdsværktøj er for kompliceret, bliver det sikkert ikke brugt. Brugervenlighed er endnu vigtigere for netbaserede samarbejdsværktøjer end for andre programmer, fordi brugen af dem forudsætter, at alle deltagere er med.

3. Det skal være billigt. Store dyre systemer, som lover meget, men som er vanskelige at afprøve før alle er med, har svært ved at slå igennem.

Artiklen er ikke et resultat af en objektiv undersøgelse og ikke et forsøg på at lave en dækkende beskrivelse af eksisterende teknologier til samarbejde via nettet. Empirien består af førstehåndserfaringer, hvilket naturligvis begrænser anvendeligheden til problemstillinger og situationer, som minder om dem, der omtales. Hensigten med artiklen er at belyse nogle af de muligheder, som ligger og venter på at blive taget i anvendelse, og som rummer potentialer for et forbedret samarbejde universitetsfolk imellem.

\section{Netbaserede praksisfællesskaber}

Skal man samarbejde, må man også kommunikere. Dette gælder, hvad enten der er tale om læring gennem fælles projektarbejde eller om undervisnings- forsknings- eller foreningssamarbejde, som skal fungere på tværs at geografiske afstande. Der findes mange forståelser af, hvad kommunikation er, og hvorledes kommunikationen påvirkes, når elektroniske kanaler benyttes. Marianne Georgsen diskuterer i sin artikel Læring, kommunikation og samarbejde i virtuelle rum (Georgsen 2003) hvorledes virtuelt samarbejde får stor - og større betydning for computer-støttet kollaborativ læring, end tilfældet er i en mere traditionel opfattelse af læring. Med udgangspunkt i Herbert Clarks arbejder om bl.a. sprogforståelse (Clark 1996) diskuterer hun, hvordan forskellige niveauer af fundering kan benyttes og evt. være nødvendige for at sikre forståelsen i en virtuel kommunikation. Ved fundering forstås her opmcerksomhed. Man viser, at man er med i kommunikationen ved at vise, at man er opmærksom. En stærk grad af fundering kan være nødvendig eller ønskelig i enkelte situationer og kan fx komme til udtryk 
i, at en part i kommunikationen udbeder sig, at den anden part gentager præcist, hvad der er blevet sagt. Som vi skal se i beskrivelsen af de praktiske eksempler, vil der være en lang række overvejelser i spil, når den vigtige beslutning om valg af kommunikationsteknologi skal træffes. Opgaverne er forskellige, folk er forskellige, og vaner og kultur varierer. Der kan være mange grunde til sammenbrud af kommunikation, og måske er en af de allervigtigste de sociokulturelle faktorer, som ikke kun er forankret i sproget, men endnu mere er udtryk for, at vi forstår tingene forskelligt. Vi rejser gerne til kolleger i fremmede kulturer og kommer gennem rejseoplevelserne til bedre at forstå disse. Når vi efterfølgende kommunikerer $\mathrm{fx}$ med email, er vi bedre rustede til den korte, skriftlige kommunikation. Selvom kommunikationen af og til bryder sammen, kan kommunikation altså i andre situationer være med til at overvinde sociokulturelle barrierer, specielt hvis den i perioder er mere tæt og umiddelbar (som ved fysiske møder, video eller audio).

I forbindelse med samarbejde mellem universitetsfolk har det betydning at være en del af et fællesskab. Etienne Wenger har beskrevet, hvorledes praksisfællesskaber kan opstå og udvikles (Wenger 1998) og hvorledes det er typisk at
1. Praksisfellesskaber har et fagligt fokus,
2. Deltagerne er indstillet på at arbejde sammen,
3. Der foregår erfaringsudveksling og opsamling.

Idéerne om praksisfællesskaber er primært udviklet og beskrevet i forbindelse med uddannelse og i et miljø med fysisk nærvær, men i senere arbejder har Wenger udvidet begrebet til også at omfatte domænerne: organisationer, ledelse, foreningssamarbejde, den sociale sektor, og international udvikling (Se http://www.ewenger.com og http://www.ewenger.com/theory). At Wenger mener, at idéerne om praksisfællesskaber er aktuelle i forbindelse med webbaseret arbejde fremgår af følgende citat:

"New technologies such as the Internet have extended the reach of our interactions beyond the geographical limitations of traditional communities, but the increase in flow of information does not obviate the need for community. In fact, it expands the possibilities for community and calls for new kinds of communities based on shared practice." (http://www.ewenger.com/theory).

Wenger har forfattet en nyttig gennemgang af teknologier til at understøtte praksisfællesskaber, "Supporting communities of practice, a survey of community-oriented technologies", som kan downloades fra http://www.ewenger.com/tech.

For at opretholde en følelse af nærhed og styrke af et fællesskab har tidsfaktoren stor betydning, se fx (Frederiksen 2004). Det er med andre ord vigtigt, at man får svar, når man spørger, at man kan lave tidsmæssige aftaler, som indbyrdes anerkendes som bindende, og at der er en vis frekvens i kommunikationen. Disse forhold, som synes at være meget generelle og betydende for praksisfællesskaber, kan medvirke til at gøre det særdeles vanskeligt at opbygge og vedligeholde fællesskaber på tværs af store geografiske afstande.

Mange faglige selskaber afholder måske bestyrelsesmøder to-tre gange pr. år og oplever, at det mellem møderne kan være meget vanskeligt at skabe og fastholde en faglig aktivitet. Fysiske møder er velegnede til at udveksle erfaringer og idéer, lære hinanden at kende og til at drøfte og argumentere om fælles sager og træffe fælles beslutninger, fx om hvem der inden næste møde skal gøre et bestemt stykke arbejde. Når det derimod kommer til at lave det konkrete arbejde, er fysiske møder næppe den mest effektive metode. Der er altså behov for, at individer eller mindre grupper færdiggør et stykke arbejde, fx et udkast til et notat. Efterføl- 
gende kan man så forhandle, rette og justere for til sidst, efter en iterativ proces, at nå frem til et endeligt resultat. Det er i sådanne situationer, at netbaseret samarbejde kan åbne for nye muligheder, som ellers ville have været utænkelige.

\section{Egne praktiske erfaringer}

\section{Samarbejde og videndeling i forbindelse med undervisning og læring}

Igennem snart to år har jeg været studerende på uddannelsen Master i IKT og læering som udbydes i et samarbejde mellem Aalborg Universitet, Aarhus Universitet, Roskilde Universitetscenter, Danmarks Pædagogiske Universitet, og Handelshøjskolen i København. Mere om uddannelsen på dens hjemmeside http://www.hum.aau.dk/mil/. Se også Fibiger et al. (2004).

I forbindelse med uddannelsen gennemføres en række projektarbejder, som typisk foregår i grupper med deltagere placeret rundt om i landet. Til støtte for samarbejdet i forbindelse med projektarbejdet benyttes til den asynkrone kommunikation e-læringsplatformen Virtual University (VU). Underviserne lægger materialer, spørgsmål, eksamenskrav og vejledning ud på platformen, mens kursisterne benytter platformen til at kommunikere/diskutere både i og på tværs af grupperne. Besvarelser på projektopgaver afleveres ligeledes i systemet enten ved upload af et dokument eller ved indlæg i et af de mange diskussionsfora. Undervisere og studerende mødes til weekendseminar fire gange årligt, men ellers er der ikke tilstedeværelsesundervisning. Fra starten i efteråret 2003 blev chat benyttet til møder i projektgrupperne, og siden foråret 2004 har mange grupper desuden afholdt regelmæssige IP-telefonmøder med programmet Skype (se senere). Udover disse metoder bliver e-mail benyttet i situationer, hvor man ønsker en mere privat kommunikation. I mange projektarbejder har der desuden været fysiske møder, og der har været forsøg med applikationsdeling samt videokonferencer. Ved flere lejligheder har der været erfaringsudveksling inden for gruppen af studerende, om hvorledes samarbejdet med understøttelse af diverse værktøjer har fungeret. Erfaringerne herfra vil blive resumeret i senere afsnit, som for overskuelighedens skyld er inddelt efter de enkelte værktøjer.

\section{Forenings- og udvalgsarbejde}

"Society for the Internet in Medicine" er en global forening, hvor formanden bor i Holland, kassereren i Tyskland, sekretæren i England, bestyrelsesmedlemmerne i øvrigt i USA, Argentina, Italien, og altså undertegnede i Danmark. Det er både økonomisk og tidsmæssigt umuligt at holde bestyrelsesmøder ansigt til ansigt mere end én gang om året, hvor de fleste medlemmer alligevel mødes til den årlige kongres. Til understøttelse af samarbejdet i bestyrelsen har vi igennem de seneste tre år benyttet en kombination af e-mail, chat og gruppesamarbejdsværktøjet Yahoo! Groups. Et alternativ hertil er at benytte en e-læringsplatform til at understøtte informationsdeling og specielt asynkron kommunikation. De fleste platforme har disse funktioner indbygget, og en del universitetsansatte er da også begyndt at bruge dem (Se fx Hørning Nielsen: E-læering som didaktisk provokatør (Hørning Jensen 2004)).

\section{Forsknings- og udviklingssamarbejde}

I ca. et år har jeg deltaget i et forsknings og udviklingssamarbejde, som er en del af et EU Tempus-projekt (http://www.etf.eu.int/tempus.nsf ). Formålet med Tempus-projekterne er gennem samarbejde med EU-lande at støtte udviklingen inden for de videregående uddannelser i Østeuropa, Centralasien, Balkan og Nordafrika. Formålet med det konkrete projekt er at hjælpe lægeskolerne i Bosnien-Herzegovina i gang med en modernisering, harmonisering og effektivisering af uddannelserne efter krigsårene på Balkan. Desuden lægges der op til et 
forskningssamarbejde, så behovet for effektiv videndeling og samarbejde via nettet er betydeligt. De økonomiske muligheder er meget små, og den anvendte informationsteknologi må derfor i særlig grad være både billig og brugervenlig. Udover Aarhus Universitet, deltager fra EU kolleger fra Belgien og Østrig, og projektet koordineres fra Heidelberg. Til støtte for samarbejdet anvendes open source e-læringsplatformen DotLrn (http://dotlrn.org), som er installeret i Heidelberg. Desuden eksperimenterer vi både med chat (se Figur 1) og IP-telefoni, men selv med disse simple metoder er det vanskeligt at få alle parter med i fællesskabet, så der er behov for ret hyppige fysiske møder.

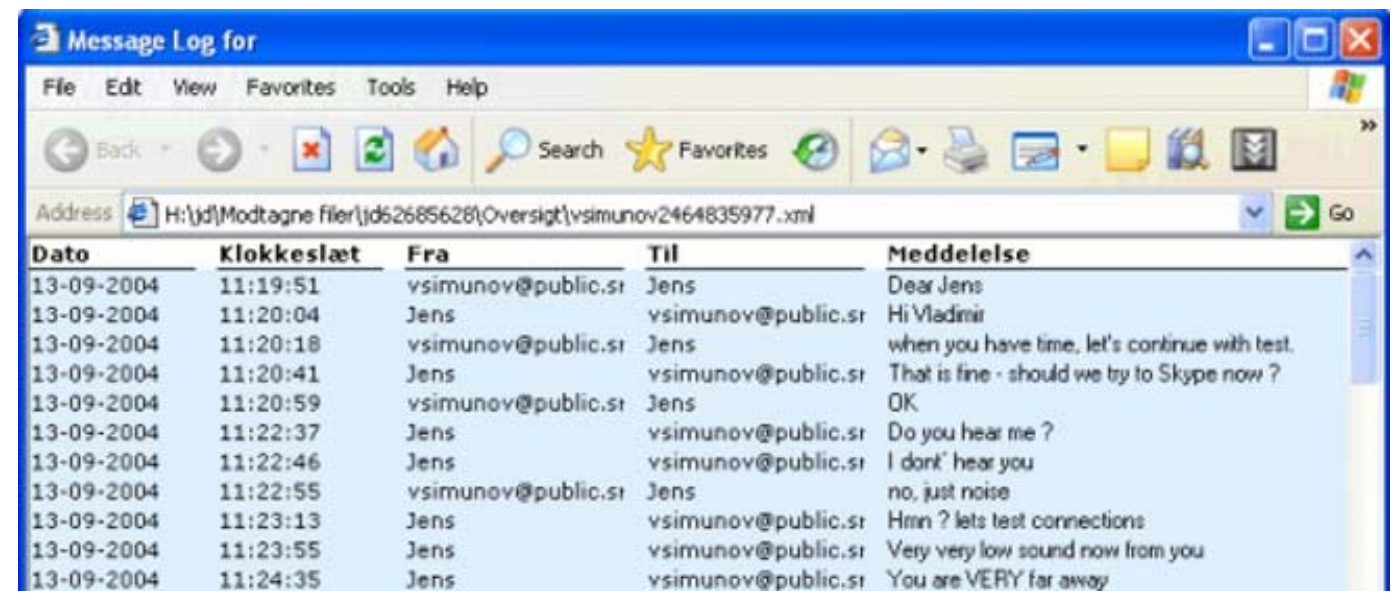

Figur 1. En kopi af Microsoft Messenger chat kan sættes til automatisk at blive gemt i XMLformatet, i folderen "Modtagne filer" under "Mine dokumenter" (se under [funktioner]- [indstillinger]-[meddelelser]). Her ses en del af en kommunikation forud for en Skype-samtale. Der er tale om samarbejde i et EU-Tempus projekt som handler om at hjæelpe de Bosniske legeskoler i gang med en curriculum reform.

\section{Hvordan en e-læringsplatform kan bruges til at støtte samarbejde og mødevirksomhed}

Vi lever i mødealderen - vores demokratiske måde at løse problemer på er forbavsende ofte den samme: Vi nedsætter et udvalg, som skal analysere situationen og skrive en indstilling, et notat eller en rapport.

En af de muligheder, man kan benytte til at støtte mødevirksomhed, er e-læringsplatforme, som i stigende grad er på vej ind på alle danske universiteter (Se fx UNEV tema 2, Elæringsplatforme - muligheder og potentialer, http://www.unev.dk/default.aspx?page=103). Selvom ikke alle platforme er lige velegnede og lettilgængelige til støtte for mødeaktivitet, findes de basale funktioner i alle platforme, så i denne sammenhæng er det ikke så vigtigt, hvilken platform der benyttes.

Platformene, som primært er til for at understøtte undervisning og læring, og som mange universitetsundervisere derfor kender i forvejen, indeholder to vigtige komponenter, der er brug for i forbindelse med møde- og udvalgsarbejde:

- Et organiseret fil-lager som deltagerne kan tilgå på en dynamisk og enkel måde,

- Faciliteter til kommunikation imellem deltagerne.

Informationslageret, som i platformen vil være internetbaseret, kan nås via en web-browser, så når et møde fx starter kl. 8 om morgenen næste dag (og materialerne ligger inde på arbej- 
det), kan man sidde hjemme og gennemse tidligere referater, mødeindkaldelsen og den seneste udgave af rapporten, som skal drøftes på morgendagens møde. Adgangen er sikret via samme autentificering, som anden aktivitet i e-læringsplatformen. Dette har to vigtige implikationer: For det første er data sikrede mod adgang for andre end dem, som bør have adgang. For det andet behøver deltagerne ikke huske et særligt brugernavn og password til mødefunktioner.

Mødeindkaldelser udsendes fra platformen via e-mails til gruppen og platformens diskussionsforum kan være et værdifuldt supplement til diskussioner ved selve mødet. Fx kan et væsentligt spørgsmål stilles til gruppen forud for mødet, så deltagerne kan starte med at tage stilling eller evt. stille opklarende spørgsmål og på denne måde være bedre forberedt til mødet.

På Aarhus Universitets e-læringsplatform (http://www.e-learning.au.dk) ser vi i disse måneder en kraftig vækst i antallet af brugere og kurser, men vi ser også, at flere og flere får øjnene op for de åbenlyse gevinster, som findes ved at bruge platformen i forbindelse med administrative opgaver. Et eksempel fra Aarhus Universitet er det tværfakultære universitetspædagogiske samarbejde, hvor vi arbejder med fælles forskningsprojekter og afholder regelmæssige møder om universitetspædagogiske emner. Aktiviteten er oprettet som et kursus, hvor deltagerne alle er registreret som undervisere. Vi deler links til litteraturreferencer og til universitetspædagogiske tidsskrifter, og vi har til stadighed adgang til dagsordner og referater samt til kommunikation internt i gruppen. Efterhånden som arbejdet i gruppen har udviklet sig, har vi fået opbygget en fælles link-samling, kalenderen i "kurset” fungerer som en udmærket oversigt, der kan konsulteres for overblik over fremtidige aktiviteter, og gruppen er blevet vænnet til at dagordener og andre materialer er tilgængelige inden møderne, så brugen af e-mails til at distribuere materialer og lave aftaler er reduceret. E-læringsplatformen ved Aarhus Universitet benyttes desuden til samarbejdsforum for UNEV's ekspertgruppe, som mødes to-tre gange årligt for at drøfte og planlægge nye temaer og andre aktiviteter i UNEV's Udviklingsforum.

\section{Chat-møder}

Ved chat-møder er al kommunikation skriftlig. Det tager længere tid at formulere sig end ved mundtlig kommunikation, udtalelserne blive kortere, og man kan opleve at deltagere, som er mere vante med tastaturet, får et forspring. Den tid det tager at indtaste en besked betyder, at nye spørgsmål kan være på vej, mens tidligere endnu ikke er besvaret - et problem, som vokser med antallet af deltagere i mødet. Både med audio-konference og med chat er deltagernes viden om hinandens tilstedeværelse og deltagelse (awareness) et centralt emne. Derfor starter mange chats typisk med $\mathrm{Hej}$ - Er du der? Funktionen er dobbelt: ud over tilstedeværelsen forhandles der også om, hvorvidt man evt. forstyrrer. Chat-møder er ikke, som Skype-møder, begrænset til kun fem deltagere.

\begin{tabular}{|c|c|}
\hline & $\begin{array}{l}\text { MSN-startside } \\
\text { E-mail-indbakke }\end{array}$ \\
\hline & Send en onlinemeddelelse... \\
\hline \multirow{4}{*}{$\begin{array}{l}\text { - Online } \\
\text { Optaget } \\
\text { Er straks tilbage } \\
\text { Ikke til stede } \\
\text { Taler i telefon } \\
\text { Til frokost } \\
\text { Vis som offline }\end{array}$} & Status \\
\hline & $\begin{array}{l}\log p \hat{s} \text { som jd@hi.au.dk } \\
\log p^{8} \ldots\end{array}$ \\
\hline & $\log$ af \\
\hline & $\begin{array}{l}\text { \&̊bn MSN Messenger } \\
\text { Afslut }\end{array}$ \\
\hline
\end{tabular}

Figur 2. Muligheder for at indstille status for nærvœr i MSN Messenger. 
Mange e-læringsplatforme har indbygget chat-funktionalitet, men de færreste kan leve op til funktionerne i moderne chat-programmer. Her er det netop vigtigt, at man kan se, om/hvornår de øvrige deltagere er online, ligesom man har brug for at kunne arbejde online, men alligevel vise, at man ikke er interesseret i forstyrrelser (Figur 2). I den fysiske verden sendes disse signaler fx ved, at man lukker døren til sit kontor, når man ikke så gerne vil forstyrres, mens den lades åben, når man gerne vil forstyrres. Disse meta-funktioner i forhold til kommunikationen forudsætter en internet-baseret brugerdatabase, hvor man kan opsøge andre brugere, og hvor den enkelte selv kan sørge for at egne personoplysningerne er korrekte og altså også har mulighed for at ændre dem. Der findes flere sådanne databaser, men en af de største er Microsofts, som benyttes af MSN Messenger (Se mere på http://messenger.msn.dk). Andre store systemer er ICQ (http://www.icq.com) og Yahoo! Messenger (http://messenger.yahoo.com). Nogle af disse systemer tillader også, at man benytter lyd og video, i MSN Messenger dog kun med to samtidige deltagere.

De aktuelle erfaringer stammer mest fra arbejdet i bestyrelsen af Society for the Internet in Medicine. Normalt har antallet af deltagere været seks til ti. Udgifter og tidsforbrug gør det i denne globale forening umuligt at operere med fysiske møder. Yahoo tillader i princippet audio-konference med op til ti samtidige brugere. Vi har afprøvet denne funktion, men desværre fundet, at visse deltagere havde problemer med kommunikationen formodentlig pga. sikkerhedsmæssige begrænsninger (firewalls). Der afholdes normalt fire - fem årlige møder, og normalt er kun ét af disse møder med fysisk tilstedeværelse. Resten afholdes med chat. Foreningen benytter Yahoo! Groups (http://www.groups.yahoo.com) (se Figur 3) til

- Fildeling (alle mødeindkaldelser, referater og andre centrale papirer),

- Meddelelser, hvor alle e-mails som sendes til bestyrelsens fælles e-mail-adresse vil blive gemt i systemet,

- "Polls" - eller afstemninger bruges fx til at fastsætte en passende mødedato, og

- Chat - ikke mindst.

\begin{tabular}{|c|c|c|c|}
\hline \multicolumn{4}{|c|}{ St Yahoo! Groups : simexec - Microsoft Internet Explorer } \\
\hline \multicolumn{4}{|c|}{ File Edit View Favarites Tools Help } \\
\hline \multicolumn{4}{|c|}{ 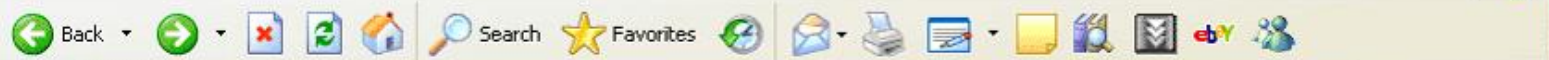 } \\
\hline \multicolumn{2}{|c|}{ Address 3 http://health.groups.yahoo.com/group/simexeci } & \multirow{2}{*}{$\begin{aligned} \vee & \rightarrow \text { Go Links } \\
& \text { Search }\end{aligned}$} & \\
\hline \multicolumn{2}{|c|}{ Yahool MrYahool Mail } & & $\hat{\imath}$ \\
\hline \multicolumn{2}{|c|}{ IIIIOOI HEALTH $\begin{array}{l}\text { Welcome, jdoerup } \\
{[\text { Sign Out, }}\end{array}$} & \multicolumn{2}{|l|}{ Health - Groups - Help } \\
\hline \multicolumn{2}{|c|}{ jdoerup·JD@hi.au.dk } & \multicolumn{2}{|c|}{ Start a Group - My Groups } \\
\hline \multicolumn{2}{|c|}{ simexec $\cdot$ closed discussion group for SIM } & \multirow{5}{*}{\multicolumn{2}{|c|}{$\begin{array}{l}\text { [Edit My Membership ] } \\
\text { Membership } \\
\text { You are a member of } \\
\text { this group } \\
\text { [Edit My Membership ] } \\
\text { [Leave Group ] }\end{array}$}} \\
\hline \multicolumn{2}{|c|}{\begin{tabular}{l|l} 
Home & Description
\end{tabular}} & & \\
\hline \multirow{2}{*}{$\begin{array}{l}\frac{\text { Messages }}{\text { Post }} \\
\text { Chat } \\
\text { Files }\end{array}$} & $\begin{array}{l}\text { Closed discussion group for the Executive Committee of the Society for the Internet in } \\
\text { Medicine. }\end{array}$ & & \\
\hline & What's New & & \\
\hline Photos & \multirow{2}{*}{$\begin{array}{c}\text { New within the last seven days: } \\
\qquad \text { Messages: } 1\end{array}$} & & \\
\hline Links & & \multirow{2}{*}{\multicolumn{2}{|c|}{$\begin{array}{l}\text { Group Info } \\
\text { Members: } 15 \\
\text { Created: Nov 29, } 2000\end{array}$}} \\
\hline \multirow{2}{*}{$\frac{\text { Polls }}{\text { Members }}$} & & & \\
\hline & View all Messages (1193) & \\
\hline Calendar & Jan 13 MEDNET 2005 - doctorhans & \multicolumn{2}{|l|}{ Group Settings } \\
\hline
\end{tabular}

Figur 3. Gruppesamarbejdsskcerm fra Yahoogroups, som benyttes af bestyrelsen for Society for the Internet in Medicine. 
Yahoo! Groups er gratis at benytte, men man må acceptere en beskeden eksposition for reklamer.

\section{Praktiske erfaringer med chat-møder}

Det er endnu mere vigtigt ved netbaserede møder end ved fysiske møder at gøre et grundigt forarbejde. Er dagsordnen på plads? Er det evt. muligt at have indstillinger til beslutninger på plads forud for mødet? Alt relevant stof skal være distribueret, og deltagerne skal være inde i stoffet.

Til forarbejdet hører også fastsættelsen af et godt mødetidspunkt. I bestyrelsen for Society for the Internet in Medicine har vi været nødt til at tænke en del på tidszoner. Der skal vælges en ordstyrer, som har til opgave at sikre, at alle relevante meninger bliver hørt, og at mødet skrider fremad. I de lidt mere komplekse chatprogrammer fremgår det under dialogvinduet, at NN skriver en meddelelse. Så ved man, at noget er på vej. Ellers kan der ved chatmøder, specielt med mange deltagere, optræde tavse perioder, hvor alle afventer input. Ved afholdelse af chatmøder skal der afsættes mere tid end ved fysiske møder, men naturligvis er de samlede besparelser i tid og penge ganske betydelige hvis rejsetid og udgifter regnes med.

Yahoo chat gemmer ikke automatisk en kopi af en chat, så hvis man har behov for at gemme "samtalen”, må man gøre det, inden man forlader chatvinduet. Dette kan fx gøres ved at markere samtalen som en tekstblok og kopiere den til et Word-dokument. Der kan være problemer med denne metode, da vi adskillige gange har været ude for, at en eller flere af deltagerne midlertidigt har været koblet af mødet, så der ikke forligger én samlet chat. I modsætning til Yahoo-chat kan MSM Messenger automatisk gemme chat-samtaler i XML formatet (Se Figur 1).

\section{Samtale og telefonkonference med Skype}

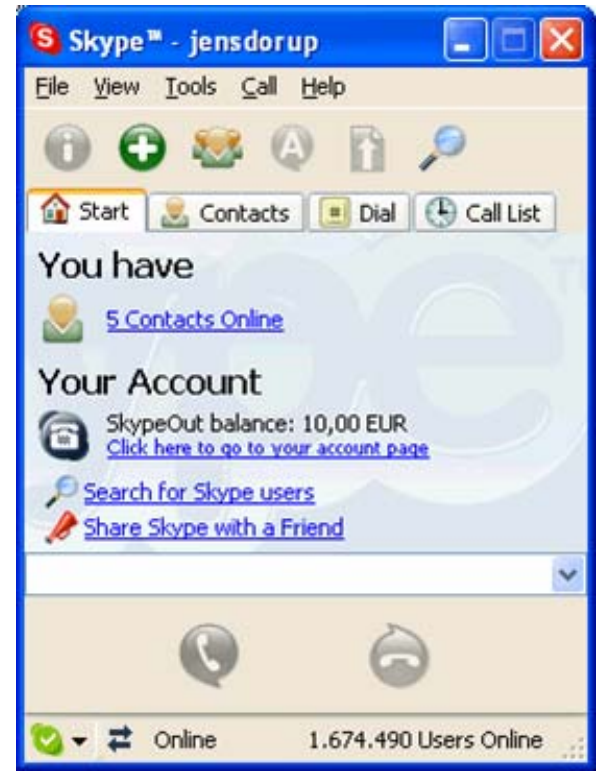

Figur 4. Startskcrmen i Skype

Skype er et ungt program (fra august 2003). Det er udviklet af et par af folkene bag det kendte KaZaa-system til fildeling via internettet. Det er gratis at downloade og installere programmet 
fra http://www.skype.com. Skype er tilgængeligt for Windows, Mac, Linux og Pocket PC. Der findes masser af hjælp med at komme i gang fra http://www.skype.com/help og http://www.skype.com/help/guides. Skype tilbyder:

- Gratis telefoni via internettet. Har man et "headset” (hovedtelefon med mikrofon) og en fast forbindelse til internettet, kan man kommunikere med lyd gratis globalt.

- Ingen (betydelige) firewallproblemer. Én kommunikationsport må altid være åben, hvis man skal surfe på internettet (port 80). Den benyttes nemlig til at surfe på websider. Mht. lyd er der andre porte (TCP- eller UDP-porte med numre over 1024), som giver bedre kvalitet, men som af og til er blokerede af sikkerhedshensyn i firewalls. Fidusen ved Skype er, at man som bruger - uden kendskab til disse tekniske detaljer ikke behøver at bekymre sig om dem. Hvis Skype ikke får forbindelse gennem de høje porte, vil port 80 nemlig automatisk blive valgt. Dette gælder fx ikke for MS Messenger eller Yahoo! Messenger. Mange oplever derfor firewall-problemer med disse systemer og andre systemer.

- Mulighed for konference med op til fem deltagere. Et telefonmøde med deltagelse af op til fem deltagere via almindelig telefoni er en bekostelig affære. Med Skype er også dette gratis. Da deltagerne kan være lokaliseret overalt på kloden, åbnes der helt nye og spændende muligheder for at styrke internationalt arbejde og samarbejde.

- Billig forbindelse fra Skype til almindelige telefoner med SkypeOut. Er man Skypebruger og vil kontakte en person på en almindelig telefon et andet sted i verden. kan det gøres for ganske små penge. Ved opkald til fastnettelefoner i den "vestlige verden" koster SkypeOut ca. det halve af taksten på telefoni i dagtid på TDC fastnet. Prisen er uafhængig af, hvor man ringer fra, men afhænger af destinationen. Lande udenfor "den vestlige verden" samt mobiltelefoner koster mere (jf. http://www.skype.com/products/skypeout/rates). Betalingen foregår ved, at man overfører enten $€$ 10eller 20 fra en bankkonto til en internet-baseret SkypeOut-konto. I forbindelse med brug kan man løbende følge med i, hvad hvert enkelt opkald koster, og hvor meget der er tilbage på kontoen (Figur 4).

Kontakten mellem brugere, som er registreret i Skypes internet-database fungerer ved, at den, som ønsker at kalde op til en anden, laver et opslag i databasen på det aktuelle navn. Det er op til hver enkelt at beslutte, hvor mange navneoplysninger, som registreres. Findes der flere brugere med mere eller mindre samme navn, fås en liste, og man kan vælge på basis af lokalitet eller andre oplysninger, som brugeren har tastet ind i forbindelse med registreringen. Såfremt navnet findes, og man forsøger at etablere kontakt, vil der fremkomme en besked på den respektive modtagerskærm, hvor modtageren af et opkald vil blive bedt om at svare på, om man vil besvare opkaldet. Brugere, som ofte tager kontakt, vil typisk oprette hinanden som kontakter, og der vil så være mulighed for at afgøre, om man er interesseret i at kunne se, hvornår man er "online” og tilgængelig i systemet. Ønsker man at være i fred, er det ret enkelt at skifte status, så man set udefra er enten usynlig, optaget, eller ikke ønsker opkald (fungerer principielt som ved MSN Messenger (Figur 2).

\section{Praktiske erfaringer med Skype}

Mange af erfaringerne med Skype stammer fra projektarbejde på uddannelsen Master i IKT og Læring, hvor projektgruppens fem medlemmer var geografisk placeret rundt om i Danmark. Vi havde tidligere afholdt chat-møder med brug af MSN Messenger, men da vi hørte om Skype, var vi interesserede i at prøve, om vi med Skype kunne opnå større effektivitet i mødet. Den første download, installering og registrering af brugernavne i Skypes navnekatalog samt start af en netbaseret konference tog mindre end en halv time, de tekniske vanskeligheder var små og vi besluttede umiddelbart at benytte systemet i det videre arbejde i gruppen. 
Det er siden blevet til mere end 25 aftenmøder, typisk af en til to timers varighed. I perioder har der været mere eller mindre faste aftaler om ugentlige møder. I perioder med højt arbejdspres har møderne været hyppigere. Det er karakteristisk, at det internetbaserede samarbejde mere har haft karakter af mødeaktivitet end af telefoni. Den centrale forskel her ligger mest i, at man ved møder har en fast aftale om tidspunkt, dagsorden varighed mv. I praksis forberedes et møde af e-mails eller indlæg i e-læringsplatformens konference, hvor man fx beder om præferencer mht. mødetidspunkt mv. Flere praktiske tekniske detaljer, og oplysninger om hvordan man kan optage lyden fra et Skypemøde, er placeret i Appendiks

\section{Perspektiver}

Internettet har gjort verden mindre, og denne udvikling vil utvivlsomt fortsætte. Det er nærliggende at antage, at video med tiden vil få større plads som en del af kommunikationen. Videokonference kræver lidt flere investeringer og lidt mere teknisk indsigt eller bistand end de teknologier, som her er omtalt. Alligevel benyttes videokonference i stigende udstrækning både til samarbejde, undervisning og forskningsformidling på tværs af nationale og internationale grænser (Mønster 2004; Dørup og Sidelmann 2004).

Der er for tiden store problemer med "hacker-" og "spam"-aktivitet på nettet. De sikkerhedsmæssige forhold gør, at universiteternes netværk er lukkede for visse former for kommunikation, herunder ofte protokoller og porte som anvendes til video. Som anført er det et krav for at komme i gang, at alle parter kan være med og hurtigt kan opleve fordele ved de netbaserede praksisfællesskaber. Det er derfor trist at måtte konstatere, at sikkerhedsmæssige forholdsregler i dag blokerer for visse anvendelser af nettet. Forhåbentlig vil der i fremtiden blive udviklet metoder til at løse disse problemer.

Erfaringerne, som omtales i nærværende artikel, viser dog, at det lader sig gøre at samarbejde effektivt via nettet uden store økonomiske investeringer og uden særlig teknisk indsigt. Netbaserede praksisfællesskaber kan hermed dannes og udvikles på tværs af sociokulturelle barrierer. Hvilke teknikker og metoder, som i en given situation vil være mest egnede, vil afhænge af intensiteten af arbejdet og frekvensen i kommunikationen. Arbejdets karakter stor betydning. Skal der skabes et konkret produkt, eller er der "kun” behov for kommunikation? Hvor stort er behovet for et fælles netbaseret filarkiv? Er der behov for at se personer eller ting med video?

Da risikoen for problemer stiger med kompleksiteten af den anvendte metode, kan det generelt anbefales at benytte den simpleste af en række alternative metoder, som kan løse en given opgave.

\section{Litteratur}

Berners-Lee, Tim. Webbets Vej Til Verden. Humlebæk: Adlandia, 2001, 1-256.

Clark, Herbert H. Using Language. Cambridge: Cambridge University Press, 1996.

Dørup, Jens og Sidelmann, Dorte. Internet video - teknik og pædagogik mødes på nettet. Tidsskrift for universiteternes efter- og videreuddannelse [online, downloaded fra www.unev.dk februar 2005] 3, 2004.

Fibiger, Bo, et al. Master in ICT and Learning Project Pedagogy and Collaboration in Virtual E-Learning. Proceeding of the 3rd european conference on e-learing. November 25, Paris: 2004.

Frederiksen, Helle. Faglig Formidling og Netfællesskaber. Det digitale nærvcr. Viden og design i nye medier. Ed. Simon B. Heilesen. Frederiksberg: Roskilde Universitetsforlag, 2004. 83. 
Georgsen, Marianne. Læring, kommunikation og samarbejde i virtuelle rum. Tidsskrift for universiteternes efter- og videreuddannelse [online, downloaded fra www.unev.dk februar 2005] 1, 2003.

Hørning Jensen, Morten. E-læring som didaktisk provokatør. om implementeringen af elæringsplatformen Claroline på Det Teologiske Fakultet, Århus Universitet. Tidsskrift for universiteternes efter- og videreuddannelse [online, downloaded fra www.unev.dk februar 2005] 2, 2004.

Mønster, Dan. Videokonference i Forskningsnettet. muligheder, erfaringer og teknologi. Tidsskrift for universiteternes efter- og videreuddannelse [online, downloaded fra www.unev.dk februar 2005] 3, 2004.

Wenger, Etienne. Communities of Practice. Learning, Meaning, and Identity. Cambridge: Cambridge University Press, 1998.

\section{Appendiks}

\section{Typiske vanskeligheder med Skype}

Det følgende kan benyttes som en checkliste, hvis man har problemer med Skype:

- Stikkene. Det hyppigste problem ved Skype-møder er, at en eller flere stik ikke er sikkert placeret i lydkortene. De små mini-jack stik er ikke specielt robuste og det sker ganske ofte, at man tror at stikket sidder korrekt, men at det alligevel ikke er stabilt tilsluttet. Så hvis lyden er helt væk, er det en god idé at starte med at kontrollere stikket

- Mikrofonen skal være aktiveret i panelet "optage kontrol”. Lydoptager-indstillingerne herunder også optage-volumen findes i Windows’ Kontrolpanel. Man skal altså vælge mikrofon som optager, og det er en god idé, at man også klikker på knappen "avanceret” og vælger $+20 \mathrm{~dB}$ boost, så mikrofonsignalet forstærkes. Optagevolumen kan herefter justeres så det nogenlunde svarer til de øvrige mødedeltageres indstilling. Hvis der nederst til højre på skærmen findes et lille højttaler-ikon, kan man også dobbeltklikke på den for hurtigt at finde frem til Windows’ lydmikser. De nævnte indstillinger kan afhænge af hvilket lydkort, som findes i computeren, ligesom de jo også fungerer anderledes på computere, der ikke er baseret på Windows.

- Problemer med båndbredden. Skype justerer båndbredden dynamisk, så der kun benyttes båndbredde, når der tales. Der benyttes op til 16 KB svarende til 128 Kbit pr sekund. Har man mindre end dette, kan man forvente forringet lydkvalitet ind imellem. Kvaliteten afhænger som omtalt også af den anvendte protokol, som altså igen afhænger af om, der er en firewall, som blokerer for de høje porte. Et telefonmodem er med andre ord normalt ikke tilstrækkelig til en god lydkvalitet. Det er vores erfaring ved Skype-møder med flere deltagere, at man opnår bedst lydkvalitet, hvis den station, som har størst båndbredde inviterer til konferencen.

- Støj. Skype indeholder en funktion, som gør at der lukkes af for lyden fra en station, som er tavs. Er der derimod støj fra en station kan denne være generende for alle deltagere i mødet (måske undtaget støjsenderen). Støj kan komme fra brummende højttalere, mobiltelefoner, computerens blæser og harddisk, løse forbindelser, men også fra omgivelserne. Skype er mere følsom for støj end almindelige telefoner. Husk evt. at indstille mikrofonvolumen på lidt mindre end den maksimale indstilling. Periodisk støj har vi også oplevet uden relation til de deltagende stationer og uden at vi har kunnet finde en årsag. 


\section{Referat af Skypemøder}

Der er flere forskellige måder, hvorpå man kan optage lyden fra et Skype-møde mhp. senere at fremstille et referat. Forbindelse af mikrofon og hovedtelefon optager to af lydkortets ind/udgange, men mange lydkort har udover stik til mikrofon og til højttaler også line-in og line-out stik. Det er muligt at forbinde line-out stikket med et line-in eller en mikrofonindgang på en anden computer og på den måde optage lyden fra et Skype-møde med et program til lydoptagelse i mp3-format, fx det gratis program FreeRecorder (http://www.freecorder.com). Der er dog det problem, at den lyd, som kommer fra den aktuelle station, ikke kommer med på line-out stikket: så enten må computeren, som benyttes som optager, forsynes med både et line-in signal og en ekstra mikrofon, som kan optage det som siges lokalt, eller antallet af deltagere i konferencen må reduceres til 4, så en optager-pc kan udfylde den femte plads i konferencen. Andre alternativer er at benytte en MP3-optager eller en kassettebåndoptager, men dette forudsætter, at en station benytter højttalere i stedet for hovedtelefon, hvilket kan medføre lidt ekko hos de øvrige deltagere.

Det kan ikke udelukkes, at andre tekniske løsninger er mulige, men den simple løsning, at udnævne en referent med papir og blyant, eller et åbent Word dokument, er jo bestemt også en mulighed. 